\title{
ОРГАНІЗАЦІЯ БЕЗПЕРЕРВНОГО ПРОФЕСІЙНОГО РОЗВИТКУ ВИКЛАДАЧІВ У СИСТЕМІ МЕДИЧНОЇ ОСВІТИ (АНАЛІТИЧНИЙ ОГЛЯД ТА ПРОПОЗИЦІї)
}

\author{
Ю. В. Вороненко, О. П. Мінцер, В. В. Краснов \\ Національна медична академія післядипломної освіти імені П. Л. Шупика
}

\section{ORGANIZATION OF TEACHER'S CONTINUING PROFESSIONAL DEVELOPMENT IN HEALTH EDUCATION SYSTEM (ANALYTICAL REVIEW AND SUGGESTIONS)}

\author{
Yu. V. Voronenko, O. P. Mintser, V. V. Krasnov \\ National Medical Academy of Post-Graduate Education by P. L. Shupyk
}

\begin{abstract}
Проведений аналіз різних концепцій підготовки викладачів у системах медичної освіти. Показана необхідність удосконалення принципів підготовки кадрів в освіті. Запропоновані стратегічні напрямки побудови системи підготовки викладачів вищих медичних навчальних закладів, що основані на сучасних світових тенденціях.
\end{abstract}

Analysis of the various teacher training in health education is performed. The necessity to improve the principles of training in education is shown. The strategic directions of medical schools teacher training construction, based on current trends of the world systems are proposed.

Вступ. Існуюча система підготовки викладачів для вищої школи побудована на кращих традиціях радянського періоду. Проте сучасні тенденції швидко мінливого світу, підвищення вимог до якості підготовки фахівців, стрімкий розвиток інформаційних технологій тощо актуалізують питання про концептуальне вдосконалення всісї системи.

Школа підготовки педагогічних кадрів у галузевих освітніх установах також має формальний підхід. Як правило, основний педагогічний склад кафедр поповнюється випускниками аспірантури. Разом $з$ тим, програма очної підготовки аспірантів далеко не завжди включає педагогічний курс, а якщо він і є, то його тривалість і наповнення визначаються хаотично. Згідно з Положенням про підготовку науково-педагогічних і наукових кадрів [1] аспірант і докторант зобов'язані проходити педагогічну практику, але ця вимога не завжди виконується в установах, які готують наукові кадри і не займаються педагогічною діяльністю. У свою чергу, в навчальних закладах 3 аспірантури або докторантури тривалість і якість педагогічної підготовки не регламентуються.

Недоліки сформованого підходу можна розглянути на прикладі порядку присвоєння вчених звань, який має суто формальний характер, згідно з яким статус доцента або професора визначається терміном ро- боти на посаді та кількістю публікацій [2]. У той же час такі поняття, як створення авторської школи, професіоналізм педагога тощо, залишаються поза увагою. Як наслідок у викладачів відсутній стимул підвищувати свій педагогічний професіоналізм.

Багато питань викликає балансування викладача між трьома професійними сферами діяльності-предметною, науковою та педагогічною. Кожен викладач клінічної дисципліни (предмета) за освітою і за родом діяльності насамперед повинен бути лікарем (за базовим рівнем вищої професійної освіти). По закінченню аспірантури (докторантури), виконання та успішного захисту дисертації він здобуває науковий ступінь (кандидата чи доктора знову ж таки медичних наук). І вже в процесі освоєння досвіду педагогічної діяльності та / або набуття додаткової кваліфікації стає педагогом вищої школи. Виникає питання: яка 3 перелічених сфер діяльності є пріоритетною для викладача вищої медичної школи, а яка другорядною? У стандартах Всесвітньої асоціації медичної освіти в розділі 5.2. "Правила роботи та професійне вдосконалення співробітників” ще у 2001 році були сформульовані такі рекомендації: "Медичний навчальний заклад повинен розробити правила роботи, що описують співвідношення педагогічної, науково-дослідної та практичної медичної діяльності в ньому, а

() Ю. В. Вороненко, О. П. Мінцер, В. В. Краснов 
також стимулюють академічну діяльність співробітників, як в науково-дослідній, так і в педагогічній областях".

В типовому положенні про атестацію педагогічних працівників [3] говориться про частоту обов' язкового проходження підвищення кваліфікації (не рідше одного разу на п'ять років), а також зазначається, що атестаційна комісія перевіряє якість роботи викладачів через відвідування навчальних занять та інших заходів, вивчає рівні навчальних досягнень тих, хто навчався у цього викладача, перевіряє активність викладача у заходах, пов'язаних з організацією навчально-виховної роботи, тощо.

Але в положенні про атестацію наукових працівників, до яких відносяться викладачі [4] медичних закладів, вимоги до критеріїв якості роботи викладачів, що можуть бути перевірені, вже відсутні.

Згідно $з$ існуючою системою підвищення кваліфікації викладачів короткочасне циклове підвищення кваліфікації тривалістю 78 та 156 годин неможливо присвятити висвітленню та освоєнню якої-небудь однієї актуальної монопроблеми, наприклад, педагогічних вимірювань, проектування освітніх програм тощо.

Для підвищення кваліфікації викладачів медичних навчальних закладів деякі університети укладають договори 3 класичними навчальними закладами та здійснюють взаємодію з традиційною системою підготовки викладачів. Але, згідно з специфікою роботи традиційної системи підготовки викладачів, відповідні структури мають досить віддалене уявлення про професійну діяльність лікарів-науковцівпедагогів у різноманітних і складних предметних областях їх професійної діяльності. Саме тому результативність подібної підготовки залишається під питанням.

Ще одне невирішене питання стосується формування загальних (універсальних) компетенцій, про які вже більше десяти років говорить Свропа. Як відомо, виділяють три типи загальних компетенцій:

1. Інструментальні компетенції, що включають: пізнавальні, методологічні, технологічні і лінгвістичні здібності. Короткий перелік: здатність до письмової та усної комунікації рідною мовою, знання другої мови, навички роботи з комп'ютером, навички управління інформацією, дослідницькі навички.

2. Соціально-особистісні компетенціі, що включають: індивідуальні здібності типу соціальних навичок (навичок соціальної взаємодії і співпраці). Короткий перелік: толерантність, дотримання етичних норм у відношенні до інших людей і відносно природи (прин- ципи біоетики); здатність навчатися, здатність до критики та самокритики; креативність тощо.

3. Системні компетенції, до складу яких входять: системи здібностей і навичок (комбінації розуміння, сприйнятливості і знання, попереднє отримання інструментальних і міжособистісних компетенцій, становлення яких відбувається на більш пізніх етапах навчання). Короткий перелік: здатність до системного мислення, адаптивність і комунікабельність, наполегливість у досягненні мети, турбота про якість виконуваної роботи.

Важливим є те, що загальні компетенції мають формуватися на етапах підготовки до педагогічної діяльності та набуття професійного досвіду (аспірантура, докторантура, післядипломне навчання, магістратура, підвищення педагогічної кваліфікації, досвід практичної роботи тощо).

Основна частина. Мета - обгрунтувати та запропонувати концептуальні підходи до побудови системи підготовки викладачів вищих медичних навчальних закладів.

Принщипи підготовки викладачів вищих медичних навчальних закладів в Свропі.

Слід визнати, що система підготовки і підвищення кваліфікації педагогічних кадрів вищої школи України досить істотно відрізняється від парадигм західних країн, зокрема, наших найближчих сусідів-Свропейського Союзу. Університет на Заході - це в першу чергу науковий і тільки в другу - освітній центр. Навпаки, в українських вищих навчальних закладах, включаючи медичні, пріоритети розставлені у прямо протилежній функціональній ієрархії. Науково-дослідні завдання існують лише як придаток освітніх. При цьому, не будучи вченими, викладачі такого навчального закладу навряд чи можуть підготувати інноваційно-мислячі креативні кадри. У кращому випадку вони здатні виступати як транслятори минулих досягнень. Реалією сучасної української науки є й те, що науково-дослідна діяльність у більшої частини професорсько-викладацького складу пов'язана лише 3 підготовкою та захистом дисертацій. Отримавши ступінь, чимало викладачів свою наукову роботу фактично припиняють, а багато викладачів медичних навчальних закладів йдуть в практичну охорону здоров'я, де праця фахівця такого класу оплачується значно вище.

У сучасному, швидко мінливому світі із зростанням вимог до якості роботи медичного персоналу неухильно зростають вимоги до їх якісної підготовки i безперервного вдосконалення. Як наслідок логічно постає питання про створення системи безперерв- 
ного професійного розвитку (БПР) професорсько-викладацьких кадрів у системі медичної освіти.

Для розробки і реалізації концепції БПР у 1972 році в Копенгагені була заснована Світова асоціація медичної освіти (WFME). Мета Асоціації - сприяти комунікації серед медичних викладачів та розвитку національних асоціацій з питань медичної освіти по всій Свропі. У 2001 р. виконавчим комітетом WFME був прийнятий набір стандартів медичної освіти [5]. У числі найважливіших елементів забезпечення якості післядипломної медичної освіти окремим рядком виділений “Професорсько-викладацький склад і персонал кафедр”. У пункті 5.2 Стандарту сформульовані “"Правила роботи та професійне вдосконалення співробітників”. У них вказується: з метою підвищення якості академічної діяльності співробітників рекомендовано включити навчання, підвищення кваліфікації та сертифікацію викладачів медичних навчальних закладів 3 проблем педагогіки.

Сучасний ракурс змін в області ідеології навчання викладацьких кадрів медичних навчальних закладів був заданий Болонською декларацією. У 2005 році Україна офіційно підтримала Болонський процес i прийняла на себе відповідальні зобов’ язання “робити кроки по внесенню змін у національну політику 3 тим, щоб система вищої освіти та інші суспільні інститути забезпечували можливість розвитку неперервної освіти", включаючи медичну освіту [6].

Перехід на сучасну систему навчання викладачів, що грунтується на освіті впродовж усього життя, вимагає переосмислення iї методології, розробки принципів ефективного функціонування.

Цікавим є досвід європейських країн, з якими Україна будує взаємодію інтеграційного рівня. У ряді європейських країн при підготовці кадрів для всіх сфер педагогічної діяльності наголос робиться на навчанні управління самоосвітою і плануванні навчальної діяльності, а також на індивідуальні форми навчання. Для управління цим процесом був спеціально створений Міжнародний інститут планування та управління освітою ЮНЕСКО (IIPE). Програми підготовки в IIPЕ розроблені з актуальних проблем управління i планування освітою і діляться на п'ять категорій:

- програми поглибленої підготовки;

- програми стажерів;

- майстерні та спеціальні курси;

- семінари та форуми з освітньої політики;

- концепція та поширення дидактичних матеріалів (для викладацьких кадрів медичних факультетів університетів - Віртуальні університети франкофонії) [7].
Крім державних структур підготовкою і підвищенням кваліфікації викладацьких кадрів медичних навчальних закладів активно займається Національна асоціація медичної освіти (CIDMEF). Групою її експертів були визначені 3 рівні педагогічної компетентності і відповідні цим компетенціям рівні навчання педагогічних кадрів.

Перший рівень - це мінімально необхідна освіта починаючого викладача (базові знання психології викладання та навчального планування, первинні навички роботи в якості т'ютора).

Другий рівень орієнтований на навчання штатного викладача, здатного розробляти навчальні плани, програми міждисциплінарних модулів, брати участь у комплексному оцінюванні досягнень студентів.

Третій рівень визначає компетентність експерта в певній сфері (навички та вміння в навчанні т'юторів, дослідженнях в освіті, науках про контроль знань, оцінці якості освіти, володінні навичками комплексної підсумкової державної атестації студентів, сертифікації освітніх програм тощо).

Ця таксономія рівнів кваліфікації вважається базовою для підготовки до педагогічної діяльності викладачів медичних факультетів університетів ряду країн: для першого рівня - обов’ язкова освіта кандидатів на пост університетського асистента (або клінічного асистента); для другого рівня - сертифікована педагогічна освіта; для третього - освоєння магістерської програми “науки про навчання”, докторантура з педагогіки та / або навчальне стажування в експертних центрах.

Навчання починаючого викладача здійснюється безперервно впродовж усього навчального року на базі медичних коледжів, шкіл, факультетів медичних університетів, що мають спеціалізовані медико-педагогічні підрозділи. Наприклад, в університеті Ніцци заняття для т'юторів проводяться у формі щомісячних дводенних семінарів-тренінгів. Заняття відвідують як початківці-викладачі, так і практикуючі лікарі, які займаються зі студентами в університетських клініках. Освоєння освітніх програм початкового рівня завершується сертифікаційними іспитами і видачею сертифіката викладача медичного навчального закладу.

Для всіх викладачів університету Ніцци обов' язковим $\epsilon$ щорічне протягом 8-10 днів навчання з різних проблем педагогічної діяльності в медичному навчальному закладі. Це може бути освоєння нових симуляційних технологій навчання студентів, навчання навичкам проектування міждисциплінарних програм навчальних модулів тощо. За підсумками навчального року проводяться щорічні педагогічні конгреси. 
В університетах Франції поширене навчання викладачів в процесі виконання різного роду освітніх проектів, що ініційовані як самими викладачами, так і адміністраціями факультетів. Як правило, це проекти, що потребують великих предметно-професійних та інженерних знань. Тому для їх виконання формують змішані мультидисциплінарні команди.

Основною тенденцією побудови післядипломної педагогічної освіти в Європі є індивідуалізація навчання, що дозволяє забезпечити оптимальні умови для особистісного та професійного зростання кожного педагога з урахуванням його індивідуальних особливостей. Індивідуалізація навчального процесу здійснюється кількома шляхами:

1. Складання індивідуального навчального плану студента спільно з викладачем-консультантом, який $\epsilon$ офіційною сполучною ланкою між тим, хто навчається, і освітньою структурою. У ньому зафіксовані освітні програми, які планує засвоїти той, хто навчається, зміст навчання, тривалість навчання та форми оплати.

2. Створення “портфоліо”, тобто індивідуальної картотеки, в якій містяться сертифікати, дипломи та інші документи, що підтверджують вже наявні в учня знання, уміння, компетенції.

3. Обов'язковий супровід процесу навчання викладачем-консультантом, який допомагає керувати процесом навчання з моменту вибору освітньої програми, так і у всіх скрутних ситуаціях, що виникають в ході освітнього процесу у того, хто навчається.

Не менш цікавий досвід безперервного навчання професорсько-викладацьких кадрів накопичений колегами медичних факультетів університетів Німеччини. Для розвитку факультету в 2000 році в Рурському університеті Бохума був заснований Центр медичного навчання, перетворений пізніше в Центр медичної дидактики (MeDiBo), в якому сформульовані такі пріоритети та цілі діяльності:

- підготовка компетентних експертів 3 питань вищої медичної освіти;

- впровадження інновацій у сферу вищої медичної освіти;

- поліпшення якості вищої медичної освіти;

- підтримка досліджень у сфері вищої медичної освіти;

- стимулювання мотивації викладачів до індивідуальної кар'єри в професії.

Одним з основних принципів навчання в Центрі медичної дидактики є поєднання предметно-професійної та дидактичної складових викладацької діяльності, що реалізується на підставі роботи мультипрофесійної команди.
У країнах Європи також використовується покроковий підхід до кваліфікаційної підготовки викладачів медичних факультетів, що забезпечується різноманіттям програм навчання, пропонованих для різних категорій викладачів, які навчаються, і різних рівнів навчання. При цьому тривалість навчання варіює від дводенних тренінгів до дворічних магістерських програм 3 медичної дидактики.

Для розширення можливостей навчання викладацьких кадрів медичних факультетів університетів у Німеччині в 2009 р. було засновано міжвузівське об'єднання - Державна медична академія Landesakademie North Rhine-Westfalia, членами якої стали 8 університетів 3 медичними факультетами на території Землі Північний Рейн-Вестфалія.

Крім університетських структур в Німеччині активно функціонує громадська організація GMA(Gesellschaft fur MedizinischeAusbildung-науковетовариство для співпраці у викладанні медицини в Німеччині, Австрії,Швейцарії). Асоційованими членами суспільства $€$ клініки, стоматологічні клініки, ветлікарні, комітети зі спеціальних питань умедицині (проблем комунікацій, оцінювання тощо).

Найважливішим фактором ефективної професійної підготовки $є$ професійна мобільність, що дозволяє викладачеві вищої школи навчатися і підвищувати свою кваліфікацію там, де він вважає за потрібне. Для цього в рамках Болонського і Копенгагенського процесів сформульовані такі завдання:

- забезпечити порівнюваність кваліфікацій, одержуваних громадянами різних країн;

- розширити можливості освоєння кваліфікацій, в тому числі і шляхом поступового накопичення одиниць кваліфікацій (так званих “кредитних одиниць”);

- визначати кваліфікації, що отримані в ході попередньої трудової діяльності.

Рамка кваліфікачій як основа професійної мобільності.

Найважливішим фактором ефективної професійної та особистісної самореалізації викладача вищої школи є професійна мобільність, що дозволяє йому навчатися і підвищувати свою кваліфікацію там, де він вважає за потрібне. Для цього в рамках Болонського і Копенгагенського процесів сформульовані такі завдання:

- забезпечення порівнянності кваліфікацій, одержуваних громадянами різних країн;

- розширення можливостей освоєння кваліфікацій, в тому числі і шляхом поступового накопичення одиниць кваліфікацій (“кредитних одиниць”);

- визнання кваліфікацій, отриманих в ході попередньої трудової діяльності і в результаті як формального, так і неформального навчання [8]. 
В основі рамки кваліфікацій лежить ряд принципів, основними з яких є:

- варіативність, що забезпечує можливості входження в освітню траєкторію залежно від уже наявного рівня знань, умінь (компетенцій);

- забезпечення рівних прав на навчання;

- забезпечення можливості продовження навчання, як по горизонталі, так і по вертикалі,

- зміна навчальної траєкторії в будь-який момент навчання.

В Україні національна рамка кваліфікацій була затверджена відповідною постановою Кабінету Міністрів України [9]. Завдання Національної рамки кваліфікацій полягає в забезпеченні можливості вибудовування множинних траєкторій навчання, що приводять до отримання конкретної кваліфікації та підвищення кваліфікаційного рівня.

3 опису кваліфікаційних рівнів випливає, що від педагога вищої медичної школи потрібна наявність умінь і відповідальності за:

- покращення результатів власної навчальної та/ або професійної діяльності і результатів діяльності інших;

- відповідальність за професійний розвиток окремих осіб та/або груп осіб;

- відповідальність за розвиток професійного знання і практик, оцінку стратегічного розвитку команди;

- донесення до фахівців і нефахівців інформації, ідей, проблем, рішень та власного досвіду в галузі професійної діяльності;

- зрозуміле і недвозначне донесення власних висновків, а також знань та пояснень, що їх обгрунтовують, до фахівців і нефахівців, зокрема до осіб, які навчаються;

- здатність до подальшого навчання, яке значною мірою $€$ автономним та самостійним, ініціювання інноваційних комплексних проектів, лідерство та повна автономність під час їх реалізації;

- здатність саморозвиватися і самовдосконалюватися протягом життя, відповідальність за навчання та розвиток інших тощо.

Разом $з$ тим, аналіз чинних документів, які регламентують функціонування системи підвищення кваліфікації науково-педагогічних кадрів медичних навчальних закладів, не переконує в їх достатності для використання при розробці професійних стандартів безперервного навчання викладачів. У зв' язку з цим, актуальною вимогою $є$ створення галузевої рамки кваліфікацій. Для досягнення описаних компетенцій недостатньо навчання навіть протягом шести тижнів. Навчання повинно тривати увесь період становлен- ня викладача, а потім удосконалюватись і підтримуватися впродовж усієї його професійної діяльності.

Крім того, вважаємо за необхідне особливо підкреслити той факт, що підготовка викладачів $€$ своєрідною з педагогічної точки зору, оскільки викладач повинен вміти не тільки передавати знання у своїй предметній області, але і вчити своїх слухачів умінням самим викладати.

У свою чергу, навчання дорослих має свою специфіку, принципами якої займається ціла предметна область, яка носить назву “андрагогіка".

Вважаємо, що професійні напрямки розвитку викладачів вищої медичної школи необхідно проводити за такими напрямами:

1. Професійна базова педагогічна освіта.

2. Методика викладання дисциплін.

3. Методика викладання конкретної медичної дисципліни, яка є основою професійної діяльності лікаря.

4. Методика і психологія управління навчальним процесом.

5. Методика самоосвіти.

6. Соціально-особистісні/комунікативні компетенції.

7. Організація та проведення досліджень.

Додатково до базової медичної освіти лікар-викладач повинен пройти як мінімум 2-річну підготовку за програмою “Викладач вищої школи”, в процесі якої освоїти відповідні компоненти з комплексної психолого-педагогічної, соціально-економічної та інформаційно-технологічної підготовки до педагогічної діяльності у вищому навчальному закладі. Освіта за даною програмою може починатися вже в рамках аспірантури та магістратури.

У європейських країнах проектування програм додаткового навчання науково-педагогічних кадрів також здійснюється на основі компетенцій. Прикладом такого підходу може служити досвід медичного факультету Рурського університету Бохума. В університеті проектуванням і реалізацією програм підготовки та підвищення кваліфікації викладацьких кадрів займається Центр медичної дидактики. Для проектування освітніх програми було виділено найбільш актуальний, відповідний державному освітньому стандарту і профілю професії, склад компетенцій. Разом 3 тим, поряд $з$ обов'язковим для освоєння складом компетенцій (інваріантним) викладачам пропонувалися (вже на рівні компетенцій) можливості варіативних компетенцій, які педагог хотів би опанувати за власним вибором (табл. 1).

3 представленого в таблиці матеріалу випливає, що в ієрархії пріоритетів підготовки до викладацької діяльності та посилення її ефективності ключова роль на- 
Таблиця 1. Склад компетенцій викладача медичного навчального закладу, представлений фахівцями Центру медичної дидактики Рурського університету Бохума

\begin{tabular}{|l|l|l|}
\hline \multicolumn{1}{|c|}{ Вид компетенцій } & \multicolumn{1}{|c|}{ Найменування компетенцій } & Варіативність \\
\hline $\begin{array}{l}\text { Предметні (відносяться до предметної } \\
\text { області і до обраної галузі медицини) }\end{array}$ & $\begin{array}{l}\text { Медико-експертні компетенції (уміння і здатності } \\
\text { до діяльності в обраній галузі медицини) }\end{array}$ & обов'язкові \\
\hline \multirow{2}{*}{ Загальні } & $\begin{array}{l}\text { Соціально-особистісні/комунікативні компетенції } \\
\text { (навички соціальної взаємодії і співпраці) }\end{array}$ & обов'язкові \\
\cline { 2 - 4 } & $\begin{array}{l}\text { Дидактичні компетенції (здатності до } \\
\text { педагогічної діяльності) }\end{array}$ & обов’язкові \\
\cline { 2 - 4 } & $\begin{array}{l}\text { Управлінські компетенції (здатності управління } \\
\text { навчанням і персоналом) }\end{array}$ & на вибір \\
\cline { 2 - 4 } & $\begin{array}{l}\text { Дослідницька (навички наукових досліджень в } \\
\text { медицині і педагогіці) }\end{array}$ & на вибір \\
\hline
\end{tabular}

лежить предметним компетенціями, що належать до предметної області і до обраної галузі медицини. Що стосується дидактичних компетенцій, то вони віднесені до класу загальних компетенцій, що забезпечують успіх освоєння професійних, пов'язаних з предметною областю умінь і навичок. Причому більш значимими, ніж дидактичні, визнаються особистісні/ комунікативні компетенції викладача, що формують практичні навички соціальної взаємодії суб' єктів освітнього та лікувального процесів.

Специфіка побудови накопичувальної кредитної системи навчання викладачів медичних навчальних закладів на основі модульних програм.

Система підготовки викладачів побудована на класичній, лінійній схемі. Для забезпечення індивідуальних маршрутів навчання та підтримки переривчастого навчання по накопичувальній системі вкрай важливо введення кредитно-модульних структур освітніх програм.

Досвід створення систем обліку навчальної діяльності в Україні існує. Він реалізований при організації безперервної підготовки лікарів і заснований на фіксації їх освітньої діяльності між передатестаційними циклами [10].

У Росії вже введена кредитно-модульна персоніфікована накопичувальна система підвищення кваліфікації педагогічних працівників [11]. Вона грунтується на підсумовуванні результатів засвоєння модулів в структурі освітньої програми, за якою проводиться навчання. Накопичувальна система була введена 3 метою створення умов для реалізації безперервної освіти педагогічних працівників. Вона дозволяє працівнику освіти конструювати індивідуальний освітній маршрут, тобто самостійно вибирати зміст, терміни, режим навчання з урахуванням своїх професійних потреб, потреб освітнього закладу, в якому він працює, $\mathrm{i}$ рівня кваліфікації. При цьому конструювання освітньої програми підвищення кваліфікації припускає обов’ яз- кове включення до їі складу інваріантної (обов’язкова частина) та варіативної (що формується за запитом слухача) частин. Весь освітній маршрут і, відповідно, програма грунтуються на модульних технологіях.

Модульне навчання, з одного боку, орієнтоване переважно на самостійну діяльність слухачів - від самостійного вибору освітнього маршруту до освоєння сконструйованої за безпосередньої участі учня модульної освітньої програми. 3 іншого боку, істотно змінюється роль викладачів, які займаються організацією навчання професорсько-викладацького складу. 3 транслятора готових знань вони перетворюються на управлінців процесом освіти та самоосвіти, помічників і консультантів тих, хто навчається, в освоєнні індивідуально спланованої програми.

При побудові індивідуального маршруту навчання у слухача 3'являється можливість:

- брати участь у проектуванні власного освітнього маршруту;

- самостійно формувати навчальний план і вибирати навчальні модулі;

• освоювати навички роботи в команді-малій групі 3 метою подалышого перенесення цих навичок на роботу зі студентами;

• оволодівати навичками самостійної роботи в області освітніх досліджень.

При організації навчання за індивідуальними маршрутами необхідна організація підтримки подібної системи. У такому випадку істотно змінюються ролі фахівців, які забезпечують функціонування системи підготовки викладачів. Викладач повинен володіти компетенціями консультанта, т'ютора, модератора, фасилітатора тощо. Подібні фахівці повинні здійснювати підтримку самостійної роботи слухачів, керівництво індивідуальними та груповими дослідницькими проектами.

Зміна професійної позиції викладача приводить до того, що слухач і викладач в процесі навчання висту- 
пають як партнери. Викладач організує освітній процес з урахуванням освоєння слухачами і колегами викладачами нових видів діяльності, нових способів вирішення навчальних проблем, тим самим підсилює особистісну спрямованість того, хто навчається [12].

Однією з проблем впровадження подібного підходу $є$ те, що викладачі не мають навичок до самостійного навчання. Їм недостатньо знайома нова парадигма, в якій тому, хто навчається, належить центральна роль, як самостійному суб'єкту діяльності, а викладачу - роль наставника, готового навчити вмінням і навичкам самостійно знаходити і освоювати нові знання, працювати зі зростаючими масивами інформації, ефективно працювати у медійному освітньому середовищі і багатьом іншим навичкам самостійного навчання, що будуть затребувані протягом всього життя в професії [13].

Аналіз можливих варіантів організацї системи підготовки викладачів медичних навчальних закладів на основі вимог стандартів WFME.

Система підготовки викладачів медичних навчаль- них закладів регламентується тимчасовим положенням 1993 року [14]. 3 того часу відбулося дуже багато концептуальних змін в області інформаційних технологій, способів передачі знань, потреб сфери охорони здоров'я в якості підготовки кадрів тощо. У зв’ язку з цим, назріла актуальна необхідність в перегляді підходів щодо підготовки педагогів та переорієнтації ії в напрямі сучасних досягнень як вітчизняної, так і зарубіжної науки і практики.

Як уже згадувалося, вимоги стандартів WFME (безперервний професійний розвиток (БПР) та післядипломна освіта (ПО)) стосуються не тільки підготовки власне лікарів, але і всієї системи забезпечення якості медичної освіти. Орієнтуючись на ці вимоги, можна вивести ряд позицій, на підставі яких повинна будуватися також і система підготовки викладачів. Для цього ми представимо аналіз, де будуть відображені пропозиції щодо реалізації вимог стандартів (пункти та назви рубрик) і форма їх можливого виконання в рамках системи медичної освіти (табл. 2).

Таблиця 2. Пропозиції щодо реалізації вимог стандартів WFME

\begin{tabular}{|c|c|c|}
\hline $\begin{array}{l}\text { № пункту } \\
\text { стандарту } \\
\text { WFME }\end{array}$ & Вимоги стандарту & Запропонована форма реалізації \\
\hline $\begin{array}{l}\text { БПР } 2.6 \\
\text { МЕНЕДЖМЕНТ } \\
\text { БПР }\end{array}$ & $\begin{array}{l}\text { Лікарі повинні нести максимальну відповідальність } \\
\text { за планування і проведення БПР, відповідного їх } \\
\text { індивідуальним потребам }\end{array}$ & $\begin{array}{l}\text { Розробка викладачем індивідуального } \\
\text { маршруту підвищення кваліфікації }\end{array}$ \\
\hline $\begin{array}{l}\text { БПР } 6.5 \\
\text { ОФІЦІЙНЕ } \\
\text { ПРОВЕДЕННЯ } \\
\text { ЗАХОДІВ БПР }\end{array}$ & $\begin{array}{l}\text { Лікарям слід мати можливість планування і, у міру } \\
\text { потреби, виконання заходів БПР, таких як } \\
\text { поглиблене вивчення предмета для досягнення більш } \\
\text { високого рівня компетентності ефективним } \\
\text { способом }\end{array}$ & $-1 /-$ \\
\hline $\begin{array}{l}\text { БПР } 6.7 \\
\text { ОТРИМАННЯ } \\
\text { ДОСВІДУ В } \\
\text { ІНШИХ } \\
\text { УСТАНОВАХ I } \\
\text { ЗА КОРДОНОМ }\end{array}$ & $\begin{array}{l}\text { Медична професія повинна сформулювати } \\
\text { стратегічну лінію, що гарантує свободу пересування } \\
\text { 3 метою підтримки можливостей лікарів набиратися } \\
\text { досвіду шляхом відвідування різних робочих місць у } \\
\text { своїй країні і за їі межами }\end{array}$ & $\begin{array}{l}\text { Індивідуальний навчальний маршрут } \\
\text { повинен складатися з базової і } \\
\text { варіативної частин. Базова частина } \\
\text { проходиться в навчальних структурах } \\
\text { при медичних ВНЗ, які мають право на } \\
\text { підготовку викладачів. Варіативна } \\
\text { частина складається за побажаннями і } \\
\text { можливостями самого викладача для } \\
\text { навчання як в Україні, так і за } \\
\text { кордоном }\end{array}$ \\
\hline $\begin{array}{l}\text { БПР 3.1 } \\
\text { ДОКУМЕН- } \\
\text { ТАЛЬНЕ } \\
\text { ВІДОБРА- } \\
\text { ЖЕННЯ } \\
\text { ПОТРЕБ ДЛЯ } \\
\text { ПЛАНУВАННЯ } \\
\text { БПР }\end{array}$ & $\begin{array}{l}\text { Головною основою планування БПР має стати } \\
\text { звернення до потреб клінічної практики і суспільної } \\
\text { охорони здоров’я. Медична професія повинна } \\
\text { ідентифікувати усвідомлені потреби лікарів і } \\
\text { доводити їх до відома відповідальних за планування } \\
\text { БПР }\end{array}$ & $\begin{array}{l}\text { Побудова системи моніторингу } \\
\text { динамічно мінливих вимог ринку і } \\
\text { навчального процесу з подальшим } \\
\text { відображенням у варіативній частині } \\
\text { рамок кваліфікацій і компетенцій } \\
\text { викладачів медичних ВНЗ. } \\
\text { Для підтримки роботи викладачів } \\
\text { може бути створений оновлюваний } \\
\text { освітній ресурс безперервного } \\
\text { професійного розвитку викладачів } \\
\text { вищої медичної школи }\end{array}$ \\
\hline
\end{tabular}


Продовження табл. 2

\begin{tabular}{|c|c|c|}
\hline $\begin{array}{l}\text { № пункту } \\
\text { стандарту } \\
\text { WFME }\end{array}$ & Вимоги стандарту & Запропонована форма реалізації \\
\hline$-1 /-$ & $\begin{array}{l}\text { Слід створювати системи, що надають документаль- } \\
\text { но підтверджені відомості для оповіщення лікарів і } \\
\text { зацікавлених осіб про якість практики, їі результати } \\
\text { в динаміці і результати порівняння з групами колег }\end{array}$ & $\begin{array}{l}\text { Створення інформаційного порталу, де } \\
\text { може розміщуватись досвід викладачів } \\
\text { про результативність їхньої } \\
\text { педагогічної практики }\end{array}$ \\
\hline $\begin{array}{l}\text { БПР } 3.2 \\
\text { ДОКУМЕН- } \\
\text { ТАЦІЯ ДІЯЛЬ- } \\
\text { НОСТІ БПР }\end{array}$ & $\begin{array}{l}\text { Завданням будь-якої системи документації БПР слід } \\
\text { вважати підтвердження реального навчання і там, де } \\
\text { це доречно, підвищення компетентності, а не лише } \\
\text { участі в заходах БПР. Лікарям слід складати } \\
\text { індивідуальні навчальні портфоліо, якими можна } \\
\text { було б поділитися з колегами }\end{array}$ & $\begin{array}{l}\text { Створення електронного портфоліо, за } \\
\text { допомогою якого можна моніторувати } \\
\text { як формальну сторону навчання, так і } \\
\text { успіхи викладача в якості засвоєння } \\
\text { матеріалу. } \\
\text { Як самостійно виконаною } \\
\text { атестаційною роботою можуть } \\
\text { виступати журнальні статті, що } \\
\text { узагальнюють результати освітніх } \\
\text { досліджень, навчально-методичні } \\
\text { посібники для студентів або досвід } \\
\text { освітньої діяльності. Звіт про } \\
\text { підготовку та впровадження } \\
\text { навчального проекту та його } \\
\text { презентація тощо }\end{array}$ \\
\hline $\begin{array}{l}\text { БПР } 4.2 \\
\text { НАВЧАЛЬНІ } \\
\text { СТРАТЕГІЇ }\end{array}$ & $\begin{array}{l}\text { За підтримки своїх професійних організацій лікарі } \\
\text { повинні розвивати здатність до систематичного } \\
\text { планування, проводити і документально відображати } \\
\text { навчання на базі практики у відповідь на виявлені } \\
\text { навчальні потреби. Повинні бути створені методики } \\
\text { самооцінки в допомогу лікарям у справі } \\
\text { ідентифікації їх навчальних потреб }\end{array}$ & $\begin{array}{l}\text { Створення на порталі тестових модулів } \\
\text { по кожній з компетенцій, на підставі } \\
\text { яких викладач може здійснювати } \\
\text { самоаналіз по успішності володіння } \\
\text { компетенціями. Виявлені недоліки } \\
\text { дозволять викладачам цілеспрямовано } \\
\text { формувати індивідуальні маршрути } \\
\text { навчання }\end{array}$ \\
\hline $\begin{array}{l}\text { БПР } 4.4 \\
\text { ВПЛИВ } \\
\text { ЛІКАРІВ НА } \\
\text { БПР }\end{array}$ & $\begin{array}{l}\text { Лікарям повинна надаватися можливість } \\
\text { обговорення їх навчальних потреб з виконавцями } \\
\text { БПР. } \\
\text { Слід створювати системи для залучення лікарів у } \\
\text { плануванні і проведенні заходів БПР }\end{array}$ & $\begin{array}{l}3 \text { метою забезпечення різноманітності } \\
\text { форм і змісту безперервного навчання } \\
\text { викладачів освітні установи повинні } \\
\text { мати у своєму розпорядженні } \\
\text { загальнодоступні освітні електронні } \\
\text { ресурси, необхідні для реалізації } \\
\text { пропонованих ними освітніх програм. } \\
\text { Програма навчання повинна бути } \\
\text { відкрита для загального доступу на } \\
\text { порталі для обговорення та врахування } \\
\text { пропозицій }\end{array}$ \\
\hline $\begin{array}{l}\text { БПР 5.3 } \\
\text { ЗВОРОТНИЙ } \\
\text { ЗВ’ЯЗОК } 3 \\
\text { ВИКОНАВ- } \\
\text { ЦЯМИ }\end{array}$ & $\begin{array}{l}\text { Конструктивні відгуки виконавцям БПР щодо їх } \\
\text { роботи та освітніх потреб лікарів повинні надаватися } \\
\text { на постійній основі. } \\
\text { Слід встановити прийнятні норми проведення БПР і } \\
\text { домогтися того, щоб всі виконавці керувалися ними. } \\
\text { Слід створювати системи регулярного зворотного } \\
\text { зв’язку з організаторами БПР і відповідальними за } \\
\text { нього органами. } \\
\text { Під зворотним зв’язком розуміють планове } \\
\text { спілкування між слухачами та інструкторами / } \\
\text { керівниками практики з метою вишукування } \\
\text { можливостей, необхідних для підвищення ефектив- } \\
\text { ності розвитку компетентності. } \\
\text { Системами регулярного зворотного зв’язку можуть } \\
\text { служити відомості про планування, виконання та } \\
\text { результати БПР для певного контингенту лікарів }\end{array}$ & $\begin{array}{l}\text { Повинна бути реалізована звітність } \\
\text { кафедр, які проводять навчання } \\
\text { викладачів. } \\
\text { Результати і оцінки повинні } \\
\text { відправлятися в методичні кабінети } \\
\text { тих навчальних закладів, де } \\
\text { безпосередньо працюють викладачі. В } \\
\text { свою чергу, методичні кабінети } \\
\text { навчальних закладів-замовників } \\
\text { навчання повинні взаємодіяти зі } \\
\text { структурами, що готують викладачів. } \\
\text { Мета такої взаємодії: узгодження } \\
\text { формування необхідних і специфічних } \\
\text { компетенцій }\end{array}$ \\
\hline
\end{tabular}


Продовження табл. 2

\begin{tabular}{|c|c|c|}
\hline $\begin{array}{l}\text { № пункту } \\
\text { стандарту } \\
\text { WFME }\end{array}$ & Вимоги стандарту & Запропонована форма реалізації \\
\hline $\begin{array}{l}\text { БПР 5.4 } \\
\text { РОЛЬ ВИЩИХ } \\
\text { МЕДИЧНИХ } \\
\text { НАВЧАЛЬНИХ } \\
\text { ЗАКЛАДІВ }\end{array}$ & $\begin{array}{l}\text { Вищим медичним навчальним закладам у співпраці } 3 \\
\text { iншими зацікавленими особами слід проводити } \\
\text { дослідження з діяльності БПР }\end{array}$ & $\begin{array}{l}\text { Кафедри та методичні кабінети } \\
\text { повинні здійснювати роботу з } \\
\text { визначення якості компетенцій у } \\
\text { викладачів і шляхів їх вдосконалення. } \\
\text { У медичному ВНЗ може бути створена } \\
\text { науково-проблемна комісія, яка буде } \\
\text { кординувати роботу кафедр з наукових } \\
\text { досліджень у сфері педагогіки та } \\
\text { психології вищої медичної освіти } \\
\end{array}$ \\
\hline $\begin{array}{l}\text { БПР } 6.3 \\
\text { ВЗАСМОДІЯ } 3 \\
\text { КОЛЕГАМИ }\end{array}$ & $\begin{array}{l}\text { БПР повинен включати досвід співпраці з колегами } \\
\text { та іншими працівниками охорони здоров’я. } \\
3 \text { метою підвищення ефективності БПР лікарям слід } \\
\text { приєднатися до освітніх спільнот. } \\
\text { Лікарям слід брати участь у вдосконаленні } \\
\text { компетентності своїх колег, включаючи лікарів- } \\
\text { стажистів (інтернів та клінічних ординаторів), } \\
\text { студентів, представників суміжних медичних } \\
\text { спеціальностей тощо. } \\
\text { В освітніх колах проходять зустрічі з колегами і } \\
\text { колективний інформаційний обмін, дискусії та } \\
\text { консультування }\end{array}$ & $\begin{array}{l}\text { С обов’язковою участь викладачів у } \\
\text { педагогічних конференціях, семінарах, } \\
\text { круглих столах. Подібна участь } \\
\text { повинна бути обов’язковим елементом } \\
\text { індивідуального навчального } \\
\text { маршруту і частиною заходів для } \\
\text { накопичення кредитів }\end{array}$ \\
\hline $\begin{array}{l}\text { БПР } 6.4 \\
\text { ІНФОРМА- } \\
\text { ЦІЙНІ } \\
\text { ТЕХНОЛОГІЇ }\end{array}$ & $\begin{array}{l}\text { Відповідне використання інформаційних та } \\
\text { комунікаційних технологій повинно функціонувати } \\
\text { як інтегральна частина процесу БПР. } \\
\text { Лікарям слід мати доступ до інформаційних та } \\
\text { комунікаційних технологій і бути компетентними в } \\
\text { їх використанні для самостійного навчання, спілку- } \\
\text { вання з колегами, здійснення пошуку інформації та } \\
\text { ведення хворих, а також організації практики }\end{array}$ & $\begin{array}{l}\text { Підвищення кваліфікації з } \\
\text { використанням дистанційних } \\
\text { технологій заохочується при складанні } \\
\text { індивідуального навчального } \\
\text { маршруту }\end{array}$ \\
\hline $\begin{array}{l}\text { БПР } 9 . \\
\text { ПОСТІЙНЕ } \\
\text { ОНОВЛЕННЯ }\end{array}$ & $\begin{array}{l}\text { Медична професія повинна ввести в ужиток } \\
\text { процедури регулярної перевірки та модернізації } \\
\text { структури, функції і якості заходів БПР з } \\
\text { коригуванням недоліків, що можуть бути виявлені. } \\
\text { Процес оновлення слід засновувати на даних } \\
\text { досліджень. У цій справі слід звернутися до таких } \\
\text { питань: } \\
\text { - адаптація місії і кінцевих результатів до рівня } \\
\text { наукового, соціально-економічного і культурного } \\
\text { розвитку суспільства; } \\
\text { - повторний розгляд та визначення компетентності } \\
\text { для інкорпорації даних медичного наукового } \\
\text { прогресу і потреб людей, які змінюються; } \\
\text { - розробка методів самооцінки та навчання на базі } \\
\text { практики в допомогу навчанню лікарів довжиною в } \\
\text { життя }\end{array}$ & $\begin{array}{l}\text { Повинна бути побудована система } \\
\text { моніторингу не тільки якості } \\
\text { підготовки викладачів, але й потреб, } \\
\text { що виникають в перспективі. Тобто } \\
\text { підготовка “на випередження" }\end{array}$ \\
\hline $\begin{array}{l}\text { ПО } 7.2 \\
\text { ЗАБЕЗПЕ- } \\
\text { ЧЕННЯ } \\
\text { ЗВОРОТНОГО } \\
\text { ЗВ'ЯЗКУ МІЖ } \\
\text { ІНСТРУК- } \\
\text { ТОРОМ I } \\
\text { СТАЖИСТОМ }\end{array}$ & $\begin{array}{l}\text { Відгуки про якість програми з боку як інструкторів, } \\
\text { так і стажистів повинні систематично активно } \\
\text { виявлятися і аналізуватися, а за результатами їх } \\
\text { аналізу - вживатися заходи. } \\
\text { Інструкторам і стажистам слід брати активну участь } \\
\text { у плануванні оцінки програм і у використанні їі } \\
\text { результатів для розвитку програм. } \\
\text { Зворотний зв’язок по програмі буде включати звіти } \\
\text { стажистів, які стосуються умов проведення курсів }\end{array}$ & $\begin{array}{l}\text { Повинна бути реалізована система } \\
\text { звітів з боку слухачів, структур, що } \\
\text { проводять підготовку, і структур, в } \\
\text { яких працюють викладачі }\end{array}$ \\
\hline
\end{tabular}


Продовження табл. 2

\begin{tabular}{|c|c|c|}
\hline $\begin{array}{c}\text { № пункту } \\
\text { стандарту } \\
\text { WFME }\end{array}$ & Вимоги стандарту & Запропонована форма реалізації \\
\hline $\begin{array}{l}\text { ПО } 7.3 \\
\text { ВИКОРИС- } \\
\text { ТАННЯ } \\
\text { РЕЗУЛЬТАТІВ } \\
\text { ПРАЦІ } \\
\text { СТАЖИСТІВ }\end{array}$ & $\begin{array}{l}\text { Слід аналізувати успіхи стажистів відносно даних і } \\
\text { кваліфікації на момент зарахування на програму. Цю } \\
\text { інформацію слід використовувати для надання } \\
\text { зворотного зв’язку комітетам, що несуть } \\
\text { відповідальність за відбір стажерів, для планування } \\
\text { програм і проведення консультування. } \\
\text { Аналіз успіхів стажиста буде включати інформацію } \\
\text { про середню тривалість підготовки, отримані бали, } \\
\text { частоту складань і провалів на іспитах, випадки } \\
\text { успішного закінчення і відсіву, а також про час, } \\
\text { проведений стажистами в роботі по інтересах своєї } \\
\text { спеціальності }\end{array}$ & $-1 /$ - \\
\hline $\begin{array}{l}\text { ПО } 7.4 \\
\text { АВТОРИЗАЦІЯ } \\
\text { І МОНІТОРИНГ } \\
\text { МІСЦЬ } \\
\text { ПРОВЕДЕННЯ } \\
\text { ПІДГОТОВКИ }\end{array}$ & $\begin{array}{l}\text { Всі програми підготовки мають бути авторизовані } \\
\text { компетентними представниками влади на основі } \\
\text { чітко визначених критеріїв та оцінки програми з тим, } \\
\text { щоб влада могла надавати офіційний статус місцю } \\
\text { навчання або проведення теоретичного курсу, а при } \\
\text { необхідності - його анулювати. } \\
\text { Компетентній владі слід створити систему } \\
\text { моніторингу місць проведення підготовки та інших } \\
\text { навчальних закладів шляхом здійснення інспекцій } \\
\text { або іншими доречними способами }\end{array}$ & $\begin{array}{l}\text { Повинна бути розроблена програма } \\
\text { “Викладач вищої школи” для базової } \\
\text { підготовки науково-педагогічних } \\
\text { кадрів медичних ВНЗ. Програма } \\
\text { повинна бути затверджена на рівні } \\
\text { МОЗ України. } \\
\text { Повинна бути створена } \\
\text { міжінституційна система контролю } \\
\text { якості програм підготовки викладачів. } \\
\text { Тільки після отримання відповідного } \\
\text { дозволу допускається навчання } \\
\text { викладачів. } \\
\text { Координація дій з розвитку і } \\
\text { вдосконалення системи професійного } \\
\text { навчання професорсько-викладацьких } \\
\text { кадрів може здійснюватися на основі } \\
\text { асоціації викладачів медичних ВНЗ. } \\
\text { Незалежні рейтинги програм і } \\
\text { організацій безперервної освіти } \\
\text { забезпечать здорову конкуренцію між } \\
\text { учасниками ринку безперервної освіти }\end{array}$ \\
\hline
\end{tabular}

У зв'язку з тим, що сучасні стандарти освіти грунтуються на компетентністному підході і останнім часом в Україні активно розробляється національна рамка кваліфікацій [9], надзвичайно актуальною стає проблема відсутності державних освітніх стандартів післядипломної освіти, особливо в напрямку підготовки викладачів медичних навчальних закладів. Необхідно врахувати, що підготовка викладачів повинна відбуватися на основі галузевої рамки кваліфікацій і на її базі повинні бути створені кваліфікаційні вимоги для всіх категорій викладачів.

Не менш важливим є створення професійних і загальних компетенцій викладачів медичних навчальних закладів та подальша розробка на їх основі варіантів модулів для конструювання різноманітних програм професійної мобільності і кваліфікаційного зростання, що забезпечують процес безперервного навчання протягом життя в професії.
Таким чином, перелік положень, на яких повинна грунтуватися система безперервного професійного розвитку викладачів медичної освіти, $€$ таким:

1. Розробка та впровадження програм первинної підготовки викладачів та безперервного професійного розвитку.

2. Розробка та впровадження нормативної бази забезпечення обов'язкового супроводу індивідуального маршруту навчання викладачем-консультантом. Впровадження школи підготовки т'юторів та фасилітаторів.

3. Введення накопичувальної кредитної системи на кшталт існуючої в системі підвищення кваліфікації лікарів.

4. Тривалість безперервного професійного розвитку складає 700 годин за п’ять років. 3 них 156 годин є обов' язковими для проходження в структурах МO3 України, що відповідають за підготовку викладачів. 
5. Введення в програму навчання 7 обов'язкових напрямків: 1) професійна базова педагогічна освіта; 2) методика викладання дисциплін; 3 ) методика викладання конкретної медичної дисципліни, яка є основою професійної діяльності лікаря; 4) методика і психологія управління навчальним процесом; 5) методика самоосвіти; 6) соціально-особистісні/комунікативні компетенції; 7) організація та проведення досліджень. Забезпечення обов'язкового терміну навчання за кожним напрямком не менш ніж 78 годин.

6. Розробка індивідуального маршруту підвищення кваліфікації викладача.

7. Забезпечення використання технологій дистанційного навчання.

8. Створення електронного портфоліо викладача, за допомогою якого можна моніторувати як формальну сторону навчання, так і успіхи викладача в якості засвоєння матеріалу.

9. Розробка програми “Викладач вищої школи” для базової підготовки науково-педагогічних кадрів медичних ВНЗ. Програма повинна бути затверджена на рівні МОЗ України.

10. Побудова системи моніторингу вимог ринку i навчального процесу з подальшим відображенням у варіативній частині рамок кваліфікацій і компетенцій викладачів медичних ВНЗ.

11. Реалізація системи звітів з боку слухачів, структур, що проводять підготовку і структур, в яких працюють викладачі.

12. Створення освітнього ресурсу підтримки безперервного професійного розвитку викладачів вищої медичної школи.

13. Створення інформаційного порталу, де може розміщуватись досвід викладачів про результативність їхньої педагогічної практики.

14. Врахування в кредитній системі статей, що узагальнюють результати освітніх досліджень, навчально-методичних посібників для студентів.

15. Створення на порталі тестових модулів по кожній з компетенцій, на підставі яких викладач може здійснювати самоаналіз по успішності володіння компетенціями. Виявлені недоліки дозволять викладачам цілеспрямовано формувати індивідуальні маршрути навчання.

16. Розробка освітніми установами загальнодоступних навчальних електронних ресурсів 3 метою підтримки самоосвіти викладачів.

17. Заохочення участі викладачів у педагогічних конференціях, семінарах, круглих столах. Подібна участь повинна бути обов'язковим елементом індивідуального навчального маршруту і частиною заходів для накопичення кредитів.

18. Створення міжвідомчої системи контролю якості програм підготовки викладачів.

Висновки. Розвиток безперервної професійної освіти стримується цілою низкою факторів, а саме:

- негнучкістю діючих законів, що регулюють діяльність освітніх закладів, а також відсутністю нормативно-правової бази для формування різноманітних моделей безперервної освіти та реалізації переваг відкритих систем (вільний вступ, відкрите індивідуальне планування навчання, можливість вибору часу, місця і темпів навчання тощо);

- жорсткими, запізнілими і відстаючими від вимог часу ліцензійними нормами, що гальмують розвиток навчальних структур, освітніх установ післядипломної професійної освіти різних організаційно-правових форм;

- відсутністю законодавчо закріпленого різноманіття форм отримання освіти та навчання;

- відсутністю єдиної системи загальнодержавних кваліфікаційних вимог та професійних стандартів БПР.

Таким чином, для створення системи БПР викладачів медичних навчальних закладів необхідно в найкоротші терміни сформувати сучасну нормативноправову базу, включаючи професійні стандарти післядипломної освіти, що враховують як вітчизняний, так і зарубіжний досвіди.

Необхідно також підкреслити, що підвищення мотивації до самостійного навчання і постійного зростання науково-педагогічної кваліфікації професорсько-викладацького складу медичних навчальних закладів, вдосконалення їх власної методичної майстерності у відповідних предметних областях повинні бути об' єктом постійної уваги з боку як самих викладачів, так і колективів, де вони працюють. Безперечно, в підвищенні мотивації викладачів не останню роль відіграють адміністрації медичних навчальних закладів. Зокрема, iї роль в плануванні навчального навантаження для викладачів, які приділяють більшу увагу власному професійному - науково-педагогічному розвитку, матеріальному стимулюванні цієї діяльності тощо.

Залишається сподіватися, що, незважаючи на повільність реформ, під впливом всесвітніх змін сучасна вітчизняна медична освіта в усіх іiі трьох фазах, які проходять викладачі вищої медичної школи 3 професійної предметно-дидактичної освіти нарешті знайде риси безперервності та упорядкується з урахуванням тенденцій європейського розвитку. 


\section{Лiтература}

1. Про затвердження Положення про підготовку науково-педагогічних і наукових кадрів : Постанова Кабінету Міністрів України №309 від 01.03.1999.

2. Про затвердження Порядку присвоєння вченого звання професора і доцента : Постанова Кабінету Міністрів України № 1149 від 27.12.2008.

3. Типове положення про атестацію педагогічних працівників : наказ Міністерства освіти і науки України № 930 від 06.10.2010.

4. Про атестацію наукових працівників : Положення Кабінету Міністрів України № 1475 від 13.08.1999.

5. World Federation for Medical Education. Global standards for quality improvement. Postgraduate Medical Education. WFME 2003. - Disponible en: http://www.wfme.org [acceso el 2 de diciembre del 2009].

6. Международные правовые акты и документы по развитию европейской интеграции в образовании и исследованиях : Европейское образовательное пространство : От Лиссабонской конвенции до Болонского процесса. - М. : Готика, 2004. - 384 с.

7. Тряпицин А. В. Зарубежные модели повышения квалификации педагогов / А. В. Тряпицин // Сборник материалов "Инновационное развитие системы постдипломного педагогического образования” / под ред. И. С. Батраковой, О. О. Жебровской. - СПб., 2009. - С. 64-66.

8. Международные правовые акты и документы по развитию европейской интеграции в образовании и исследованиях : Европейское образовательное пространство : От Лиссабонской конвенции о признании до Болонского процесса / Сост. Г. А. Лукичев и др. ; под ред. Г. А. Лукичева ; Министерство образования и науки Российской Федерации. Федеральное агентство по образованию, Федеральный центр образовательного законодательства, Национальный информационный центр по академическому признанию и мобильности. - М. : Готика, 2004. - 384 с.

9. Про затвердження Національної рамки кваліфікацій : Постанова Кабінету Міністрів України № 1341 від 23.11.2011.

10. Про затвердження Змін до Положення про проведення іспитів на передатестаційних циклах: наказ МОЗ України № 484 від 07.07.2009.

11. Типовое положение об образовательном учреждении дополнительного профессионального образования (повышения квалификации) специалистов, утвержденное : Постановление правительства РФ № 610 от 26.06.1995, Постановление правительства РФ № 213 от 10.03.2000.

12. Поспелов В. К. Проблемы перехода к уровневой системе обучения / В. К. Поспелов, Н. Н. Комиссарова // Высшее образование в России. - 2011. - № 10.-С. 8-9.

13. Мотивационная составляющая в формировании профессионально-педагогической компетенции профессорско-преподавательского состава медицинских вузов России / Н. Б. Водолазский, Е. В. Лопанова, В. А. Акулинин, А. П. Ахрамович ; под ред. А. И. Новиков и др. // Современные подходы к определению квалификационных требований к профессорско-преподавательскому составу медицинских вузов и задачи модернизации программ дидактической подготовки педагогических кадров : Материалы международного семинара в рамках проекта Tempus IV 159328-TEMPUS-1-FR-TEMPUS-SHMES “Система обучения в течение жизни для преподавателей медицинских вузов". - Омск : Издательство отдела международного сотрудничества ОмГМА, 2011.-С. 38-39.

14. Тимчасове положення про підвищення кваліфікації викладачів вищих медичних і фармацевтичних навчальних закладів, інститутів удосконалення лікарів України : наказ Міністерства охорони здоров’я України № 95 від 03.05.1993. 